\title{
TINJAUAN RINGKAS BERBAGAI TEKNIK TERKINI UNTUK MENENTUKAN KUAT GESEK EROSIF TANAH
}

\author{
Tommy Ekamitra Sutarto ${ }^{1}$ \\ ${ }^{1}$ Jurusan Teknik Sipil, Politeknik Negeri Samarinda, Jl. Cipto Mangunkusumo, Samarinda, 75131 \\ Email: ${ }^{1}$ tommysutarto@polnes.ac.id
}

\begin{abstract}
Stream bank erosion manifests in two main modes, namely mass failure and fluvial erosion. Fluvial erosion is a quasi-continuous entrainment of individual soil grains or grain flocs or chunks from the bank face due to the hydrodynamic shear flow action. It occurs under water with retreat lengths in millimeter or centimeter scale. The interaction between fluvial erosion and mass failure determines the shape and retreat rate of the stream bank (Rinaldi et al., 2008). It is not rare, fluvial erosion which occurs at the bank toe later triggers slumping of soil mass known as mass failure. Despite its importance, the mechanism of fluvial erosion is less understood. This is predominantly due to lack of technique for measuring two key bank soil parameters that determine fluvial erosion rate, e.g., erosion shear strength $\tau_{c}$ and the erodibility coefficient M (Papanicolaou et al., 2007, Grabowski et al., 2011, Sutarto et al., 2014a). The goal of this manuscript is to provide a short review on the various techniques for measuring $\tau_{c}$ and $M$ proposed and applied in various studies. The advantages and the limitations of each technique are discussed to get a glimpse on where we stand and what challenge remains to overcome.
\end{abstract}

Key words : Fluvial erosion, erosion shear strength, erodibility coefficient

\begin{abstract}
ABSTRAK
Erosi tebing sungai terjadi dalam dua model utama, yakni erosi gerusan dan longsor atau keruntuhan. Erosi gerusan ditandai dengan tergerusnya butiran atau bongkahan tanah, secara hampir kontinu, dari permukaan tebing akibat daya gerus air sungai. Erosi gerusan berlangsung di bawah muka air dan magnitudo erosi sangat kecil dalam skala millimeter hingga centimeter saja. Interaksi antara erosi gerusan dan longsor membentuk profil permukaan tebing sungai dan mendikte laju pergerakan mundur tebing sungai (Rinaldi dkk., 2008). Tidak jarang erosi gerusan, yang umumnya lebih dominan terjadi di tumit tebing, memicu longsor tebing. Meskipun demikian pentingnya peran erosi gerusan, pemahaman tentang mekanisme erosi gerusan tidak sebaik pemahaman tentang longsor tebing. Hal ini disebabkan belum adanya metode akurat yang disepakati bersama untuk mengukur dua parameter kunci tanah yang menentukan laju erosi gerusan, yakni kuat gesek erosif $\tau_{c}$ dan koefisien erodibilitas M (Papanicolaou dkk., 2007, Grabowski dkk., 2011, Sutarto dkk., 2014a). Artikel ini memaparkan hasil tinjauan ringkas tentang teknik pengukuran parameter $\tau_{c}$ dan $M$ yang ditawarkan dan sudah diaplikasikan dalam berbagai studi. Kelebihan dan kekurangan dari masing-masing teknik juga akan dibahas untuk memahami sejauh mana kemajuan yang telah dicapai dan permasalahan yang masih harus diatasi.
\end{abstract}

Kata kunci : Erosi gerusan, kuat gesek erosif, koefisien erodibilitas

\section{PENDAHULUAN}

Praktek stabilisasi tebing sungai telah banyak dilakukan untuk mencegah erosi tebing sungai yang mengancam keberadaan dan stabilitas pondasi bangunan yang berada di sekitarnya seperti rumah, abutmen jembatan, jalan, pipa PDAM, dan lahan pertanian \& perkebunan. Namun demikian, metode perlindungan tebing sungai belum berkembang dengan baik dan cenderung mahal. Stabilitas tebing sungai umumnya diuji berdasarkan teori stabilitas lereng (slope stability) dengan anggapan erosi tebing sungai terjadi dalam bentuk longsor (mass failure) semata. 
Sebaliknya, erosi tebing sungai adalah hasil interaksi antara tiga jenis proses erosi (Huang dkk., 2006; Rinaldi dan Darby, 2008), yakni longsor (mass failure), gerusan butiran (grain fluvial erosion), dan gerusan bongkahan (mass fluvial erosion). Longsor tebing (mass failure) adalah jenis erosi yang paling mudah diamati karenanya pengetahuan dan metode perhitungannya sudah lebih matang dibanding kedua jenis erosi yang lain. Sedangkan gerusan butiran (grain fluvial erosion) dan gerusan bongkahan (grain fluvial erosion) tidak mudah diamati (Gambar 1). Kedua jenis erosi ini terjadi di bawah muka air (umumnya di tumit tebing sungai) secara quasi-continuous dalam bentuk tergerusnya butiran tanah (dalam ukuran millimeter, Gambar 1a) dan bongkahan tanah (dalam ukuran centimeter, Gambar 1b) dari permukaan tebing sungai akibat tegangan gesek hidrodinamis, $\tau_{w}$, aliran sungai (Papanicolaou dkk., 2007; Rinaldi dan Darby, 2008). Erosi butiran berubah menjadi erosi bongkahan sejalan dengan meningkatnya gaya gesek hidrodinamis aliran (Vermeyen, 1995; Sutarto dkk., 2014a). Erosi butiran dan erosi bongkahan umumnya terjadi di tumit tebing sungai mengakibatkan terbentuknya lubang di sekitar tumit tebing dan kemudian memicu longsor tebing.

Studi terdahulu melaporkan bahwa erosi gerusan (fluvial erosion), baik gerusan butiran atau bongkahan, sangat mempengaruhi stabilitas tebing sungai dan menjadi pemicu longsor tebing (mass failure). Beberapa hasil survei lapangan (Lawler, 1995; Pizzuto, 2009) dan studi pemodelan komputer (Darby dkk., 2007; Rinaldi and Darby, 2008) menunjukkan bahwa erosi gerusan (fluvial erosion) yang sifatnya quasicontinuous adalah penyebab terbentuknya lubang di tumit tebing sungai (toe undercutting) dan formasi tebing kantilever, yang kemudian mengakibatkan instabilitas tebing dan longsor (mass failure). Hasil studi ini menggarisbawahi pentingnya mempertimbangkan erosi gerusan (fluvial erosion) dalam analisa stabilitas tebing sungai karena interaksinya dengan erosi longsor (mass failure).

Selain sebagai pemicu longsor, erosi gerusan ternyata memberi kontribusi sedimen yang siknifikan dalam sungai (Darby dkk., 2007) karena sifatnya yang quasi-continuous atau terjadi hampir terus menerus selama tegangan gesek hidrodinamik, $\tau_{w}$, (di permukaan tanah tebing sungai) lebih besar dari kuat gesek kritis (critical shear strength) tanah, $\tau_{c}$. Angka $\tau_{c}$ mewakili kuat gesek erosif tanah menahan gaya gerus air (Papanicolaou dkk., 2007; Sutarto, 2012). Nilai $\tau_{c}$ menentukan waktu (timing) terjadinya erosi gerusan. Sedangkan laju erosi gerusan $E$ ( $\left.\mathrm{kg} / \mathrm{m}^{2} / \mathrm{det}\right)$ ditentukan sebagai berikut: $E=M\left(\frac{\tau_{w}}{\tau_{c}}-1\right)^{m}$

dimana $M\left(\mathrm{~kg} / \mathrm{m}^{2} / \mathrm{det}\right)$ adalah koefisien erodibilitas tanah , $\tau_{w}(\mathrm{~Pa})$ adalah tegangan gesek hidrodinamik di permukaan tebing akibat aliran, dan $m$ diasumsikan nilainya 1 untuk tanah kohesif. Nilai $\tau_{c}$ dan $M$ sangat dipengaruhi oleh interaksi kompleks antara berbagai variabel fisika, biologis, dan kimiawi tanah (Grabowski, dkk., 2011) sehingga kedua parameter ini sangat sulit diukur.

Meskipun peran erosi gerusan yang begitu penting, pemahaman tentang mekanismenya masih terbatas, sehingga praktek perlindungan tebing sungai lebih diarahkan untuk menahan longsor tebing semata, misalnya dengan penurapan (dengan turap beton atau turap baja). Padahal, metode ini mahal dan mempunyai konsekuensi negatif terhadap morphologi sungai serta dapat 
melenyapkan secara permanen ekosistem tebing sungai.

Terbatasnya pemahaman tentang erosi gerusan (baik gerusan butiran maupun bongkahan) salah satunya disebabkan oleh belum berkembangnya metode pengukuran erosi gerusan (Papanicolaou dkk., 2014; Sutarto dkk., 2014a, 2014b) terutama penentuan parameter utama kuat gesek erosif, $\tau_{c}$, dan koefisien erodibilitas , $M$, sehingga penelitian di bidang ini masih terus berkembang.

Tulisan ini memberikan tinjauan ringkas beberapa metode penentuan kuat gesek erosif tanah yang ditawarkan dalam beberapa studi. Kelebihan dan kekurangan masing-masing teknik juga akan dipaparkan untuk memberikan gambaran sejauh mana kemajuan yang telah dicapai dan kekurangan yang harus diatasi.

\section{PEMBAHASAN}

\section{Teknik Pengukuran Kuat Gesek Erosif Tanah}

Berbagai teknik telah diperkenalkan dalam literatur untuk mengetahui kapan erosi gerusan mulai terjadi dan besarnya gaya gesek hidrolik yang menyebabkannnya, $\tau_{c}$. Pada dasarnya teknik tersebut dapat dibagi menjadi teknik pengukuran lapangan (in-situ technique) dan laboratorium. Teknik pengukuran lapangan umumnya melibatkan peralatan jet erosion device (Hanson dan Cook, 2004), mini flume (Aberle dkk., 2003) dan sensor cahaya (Papanicolaou dkk., 2017). Sedangkan teknik laboratorium, umumnya menggunakan saluran terbuka lurus (straight open channel flume) (Papanicolaou dkk., 2007), saluran terbuka berputar (annular rotating open channel flume) (Gharabaghi dkk., 2007), saluran terbuka berbentuk jalur balap (race-way shaped flume), saluran tertutup (closed conduit flume) (Sutarto dkk., 2014a, 2014b; Sutarto, 2015) dan silinder berputar (rotating cylinder) (Lim dan Khalili, 2009)

\section{Jet Device}

Kelebihan alat ini adalah sifatnya yang praktis dan dapat dipasang langsung tegak lurus permukaan tebing sungai yang akan diukur kuat gesek erosifnya (Gambar 2a). Pada prinsipnya, alat menembakkan jet air ke permukaan tebing, kekuatan aliran yang menumbuk tanah tebing dapat dikontrol dan diukur. Tegangan gesek kritis atau kuat gesek erosif tercapai pada saat butiran atau bongkahan tanah mulai terlepas dari permukaan yang terkena tumbukan jet air tersebut. Prosedur penggunaan alat ini secara detail dipaparkan oleh Hanson dan Cook (2004).

Meskipun alat ini bersifat praktis, namun memiliki kekurangan yang sangat mendasar yakni, erosi yang terjadi disebabkan oleh tegangan normal tumbukan air, hal ini tidak sesuai dengan mekanisme erosi gerusan yang harusnya disebabkan oleh tegangan gesek hidrodinamik aliran air yang arahnya tangensial, bukan tegak lurus, permukaan tebing (Sutarto dkk., 2014b).

\section{Mini Flume}

Seperti jet device, alat mini flume juga sifatnya praktis, ringan dan dapat dipasang langsung ke permukaan tebing sungai yang akan diukur kuat gesek erosifnya (Gambar 2b). Selain itu alat ini menerapkan tegangan gesek hidrodinamik sesuai dengan mekanisme terjadinya erosi gerusan. Alat ini pada prinsipnya sama seperti saluran tertutup berukuran mini. Aliran air dalam saluran dapat dikendalikan dan diukur menggunakan flowmeter. Kecepatan aliran dinaikkan secara bertahap setiap interval 10 hingga 15 menit sehingga permukaan tebing 
tergerus akibat gaya gesek hidrodinamik aliran. Kenaikan kecepatan aliran menyebabkan peningkatan konsentrasi sedimen terlarut (suspended sediment concentration, SSC) yang dimonitor dengan alat sensor Optical Back Scattered (OBS) 3. Data konsentrasi sedimen yang tercatat selama pengoperasian alat diolah sedemikian rupa sehingga diperoleh nilai kuat gesek erosif, $\tau_{c}$, dan koefisien erodibilitas , $M$. Prosedur penggunaan alat dan metode analisis data secara detail dipaparkan dalam artikel Aberle dkk. (2004). Sayangnya, karena ukurannnya yang kecil, alat ini menghasilkan aliran yang lemah dengan tegangan gesek yang rendah sehingga tidak dapat diterapkan pada tanah tebing sungai yang kohesif dan padat yang tidak mudah tergerus. Karena keterbatasan ini, mini flume lebih cocok diterapkan di dasar sungai atau pantai yang terdiri dari flocculent deposits yang mudah tergerus.

Sutarto dkk., 2014b).

\section{Sensor Cahaya}

Seperti Metode ini diterapkan untuk mengukur erosi gerusan (fluvial erosion) langsung di lapangan (insitu) dengan menggunakan alat sensor cahaya Photo Electronic Erosion Pin (PEEP) (Gambar 2c). Alat ini ditanam di tebing sungai untuk memberikan informasi yang sifatnya automated, localized, quasicontinuous tentang timing, durasi, dan panjang erosi yang dipengaruhi oleh perubahan tinggi muka air dan debit di dalam sungai. Setiap instalasi pengukuran erosi terdiri dari satu atau beberapa sensor PEEP, data logger, panel surya, dan satu sensor acuan (reference PEEP). Setiap sensor terdiri dari satu barisan 13 dioda photo-resistant berjarak 1,65 $\mathrm{cm}$ antara satu dengan lainnya di atas motherboard di dalam acrylic tube yang transparan dan tahan air (Gambar 2c). Panjang efektif sensor adalah 21,45 cm sama dengan panjang total barisan dioda yang terletak di bagian depan acrylic tube. Keunggulan teknik ini adalah (Papanicolaou, dkk., 2017; Sutarto, 2018): 1) mampu mendeteksi seluruh episode (full episodicity) perubahan bentuk tebing akibat gerusan, termasuk waktu mulainya erosi (event timing); 2) mampu merekam secara otomatis (automated observations) waktu (timing) dan panjang gerusan (retreat length) yang diakibatkan oleh setiap kejadian erosi (specific erosion events), informasi ini berguna untuk mengetahui hubungan antara panjang gerusan dan gaya gesek hidrodinamik yang menyebabkannya (Lawler, 1992).

Sensor bekerja dengan prinsip membangkitkan output tegangan (voltage output) berbanding lurus dengan panjang sensor yang terpapar cahaya matahari (Lawler, 1992). Sensor awalnya ditanam ke dalam tanah tebing sungai. Saat tebing sungai tergerus, sensor PEEP dan barisan dioda di dalamnya perlahanlahan tersingkap dan terkena cahaya matahari (Gambar 3). Semakin banyak dioda atau photo-cells yang terpapar cahaya matahari maka semakin besar pula output tegangan (voltage output) sensor, $V_{c S}$, yang dikirim melalui kabel ke data logger yang ditancapkan di atas tebing di belakang sensor. Informasi ini kemudian disandingkan dengan informasi tegangan gesek hidrodinamik yang menyebabkan gerusan pada saat itu. Dari sini akan diketahui hubungan antara besarnya erosi dan tegangan gesek hidrodinamik yang menyebabkan erosi di dinding sungai, juga akan diperoleh informasi tegangan gesek 
kritis $\tau_{c}$ (atau disebut juga kuat gesek erosif tanah) yang menentukan waktu mulainya erosi.

Data time series output tegangan (voltage output) dari sensor yang terekam dalam data logger diolah melalui suatu data processing routine (terdiri dari filtering, correcting, dan smoothing) yang dikembangkan untuk menyingkirkan data noise akibat pengaruh perubahan orientasi cahaya matahari dan turunnya intensitas cahaya akibat turbiditas air sungai, serta faktor lainnnya (Lawler, 1992). Data output tegangan yang sudah dibersihkan kemudian dikonversi menjadi data panjang singkapan sensor (exposure length), $L$, yang tidak lain adalah panjang erosi tebing sungai. Dengan teknik statistik moving-averaged, serial data $L$ dibuat lebih halus sehingga akhirnya dapat memperlihatkan dengan jelas timing, magnitut dan frekuensi kejadian erosi (Gambar 4).

\section{Saluran Terbuka Lurus (Straight Open Channel Flume)}

Teknik ini tergolong dalam teknik uji laboratorium karena sampel tanah dipotong dari tebing sungai kemudian dibawa ke laboratorium untuk diuji kuat gesek erosifnya di dalam saluran terbuka seperti yang ditunjukkan dalam Gambar 5a. Sampel tanah yang akan diuji diletakkan di dasar saluran. Air bersirkulasi di dalam sistem dengan bantuan pompa. Air yang ada dalam tangki penyimpanan berbahan plastik (Gambar 5a) dipompa menuju head water tank yang berada di bagian hulu saluran, kemudian air mengalir melalui saluran secara gravitasi. Aliran air dalam saluran akan memberikan tegangan gesek hidrodinamik pada permukaan sampel tanah meniru mekanisme erosi gerusan di sungai. Air kemudian mengalir masuk kembali ke tangki penyimpanan yang ada di bawah saluran

Debit aliran, $Q$, ditingkatkan secara bertahap sehingga tegangan gesek hidrodinamik, $\tau_{w}$, meningkat. Hal ini menyebabkan sampel tanah tergerus dengan besar dan laju gerusan yang makin meningkat pula. Sejalan dengan itu, konsentrasi rerata sedimen terlarut $C_{a v g}$ ikut bertambah. Gambar 6a menunjukkan tipikal plot $Q$ dan $C_{a v g}$ dari satu sampel yang diuji. Debit Q dinaikkan sekurangkurangnya lima kali. Laju erosi, $E$ $\left(\mathrm{kg} / \mathrm{m}^{2} / \mathrm{det}\right)$, untuk setiap sampel uji ditentukan sebagai berikut:

$$
E=\frac{\Delta C_{a v g} * Q}{A_{s}}
$$

dimana $\Delta C_{\text {avg }} \quad\left(\mathrm{kg} / \mathrm{m}^{3}\right) \quad$ adalah perbedaan konsentrasi sebelum dan sesudah peningkatan debit ; $Q\left(\mathrm{~m}^{3} / \mathrm{s}\right)$ adalah debit aliran; dan $A_{s}\left(\mathrm{~m}^{2}\right)$ adalah luas permukaan sampel uji. Nilai $\tau_{c}$ ditentukan untuk masingmasing sampel uji dengan memplot pasangan $E$ dan $\tau_{w}$ dan mengextrapolasi best fit line ke $E=0$ (Gambar 6b).

Aplikasi teknik saluran terbuka lurus secara detail dipaparkan dalam Papanicolaou dkk. (2007). Kelebihan teknik ini adalah: (1) Penentuan timing (dan nilai $\tau_{c}$ ) saat mulainya tanah tergerus tidak didasarkan pada observasi mata telanjang melainkan dengan analisis data secara grafis (Gambar 6b) sehingga menghindari subjektivitas dan human error. (2) Tidak seperti jet device, teknik saluran terbuka lurus menerapkan gaya gesek, bukan gaya normal, ke permukaan tanah dengan demikian lebih mendekati mekanisme erosi gerusan di sungai. Sedangkan kekurangannnya adalah: (1) Sampel uji dapat mengalami perubahan karakteristik selama pengangkutan ke laboratorium. (2) Kuat gesek 
hidrodinamik, $\tau_{w}$, yang dihasilkan terbatas karena alirannnya tidak kuat dan saluran tidak cukup panjang untuk menghasilkan aliran stabil dalam kondisi debit besar. Akibatnya teknik ini tidak cocok untuk tanah padat kohesif yang kuat gerus erosifnya tinggi.

\section{Saluran Terbuka Berputar (Rotating Annular Open Channel Flume)}

Teknik ini tergolong teknik laboratorium dimana sampel tanah tebing sungai diuji di laboratorium menggunakan saluran terbuka berbentuk lingkaran yang dapat berputar (Gambar 5b). Secara detail, metode ini dipaparkan dalam Gharabaghi dkk. (2007). Kelebihannya seperti teknik saluran terbuka lurus, ditambah dengan kemampuan menghasilkan $\tau_{w}$ yang besar karena saluran dapat diputar dengan motor penggerak. Namun demikian, keberadaan aliran sekunder cukup siknifikan karena alur yang menikung. Aliran sekunder (secondary current) akan menyebabkan distribusi tegangan gesek $\tau_{w}$ tidak merata di atas muka sampel uji.

\section{Saluran Terbuka Berbentuk Jalur Balap (Race-way Shaped Flume)}

Saluran terbuka berbentuk jalur balap (Gambar 5c) memiliki kelebihan yang sama dengan saluran terbuka lurus. Kekurangannnya adalah: (1) Sampel uji yang mudah terganggu selama pengangkutan ke laboratorium. (2) Kuat gesek hidrodinamik, $\tau_{w}$, yang dihasilkan terbatas. (3) Adanya aliran sekunder yang siknifikan.

\section{Saluran Tertutup (Closed Conduit Flume)}

Metode ini secara detail dibahas dalam Sutarto ( 2014a, 2014b, 2015).
Prosedur pengukuran dan penentuan $\tau_{c}$ sama dengan saluran terbuka lurus. Keunikan alat ini adalah salurannya berbentuk conduit penampang persegi (Gambar 7) terbuat dari plexi glass yang transparan. Aliran dalam conduit seperti aliran saluran tertutup yang kecepatannnya diatur oleh perbedaan tekanan yang ditimbulkan oleh pompa. Teknik ini memiliki kelebihan sama dengan saluran terbuka lurus ditambah 2 (dua) kelebihan lain, yakni: (1) Aliran bertekanan sehingga $\tau_{w}$ yang dihasilkan cukup besar. (2) Aliran sekunder tidak siknifikan karena saluran cukup panjang dan alurnya lurus.

\section{Saluran Berputar (Rotating Cylinder)}

Diantara semua teknik laboratorium, silinder berputar (Gambar 5d) adalah jenis alat yang paling ringan dan kecil demikian pula jumlah air dan ukuran sampel uji yang digunakan (Chapuis and Gatien, 1986). Namun demikian, persiapan sampel uji dan prosedur yang diterapkan tergolong rumit (Lim and Khalili, 2009).

\section{KESIMPULAN}

Erosi gerusan (fluvial erosion) yang terjadi di bawah muka air sangat penting untuk dipahami dan diukur karena perannnya sebagai pemicu longsor tebing sungai, dan besarnya kontribusi sedimen di sungai yang berasal dari erosi gerusan. Namun demikian, pemahaman tentang erosi gerusan hingga saat ini masih terbatas salah satunya disebabkan oleh belum berkembangnya metode pengukuran erosi gerusan (Papanicolaou dkk., 2014; Sutarto dkk., 2014a) terutama penentuan parameter utama kuat gesek erosif, $\tau_{c}$, dan koefisien erodibilitas , $M$, 
sehingga penelitian di bidang ini masih terus berkembang.

Berbagai teknik telah diperkenalkan dalam literatur untuk mengukur erosi gerusan, baik itu teknik pengukuran lapangan (in-situ technique) maupun laboratorium. Teknik lapangan (in-situ technique) umumnya lebih praktis dan cepat karena peralatan yang digunakan berukuran kecil, tidak perlu mempersiapkan sampel uji, dan alat dapat dipasang langsung di tebing sungai. Namun demikian, teknik lapangan umumnya kurang mampu memodelkan dengan tepat mekanisme aliran yang menyebabkan erosi gerusan sehingga menurunkan validitas hasil pengukuran. Hal sebaliknya terjadi pada teknik laboratorium. Dengan demikian, penelitian masih perlu terus dilakukan untuk membangun metode pengukuran yang praktis, murah, dan cepat, namun dengan akurasi hasil pengukuran yang tinggi.

\section{DAFTAR PUSTAKA}

[1] Aberle, J., Nikora, V., McLean, S., Doscher C., McEwan, I., Green, M., Goring, D., \& Walsh, J. 2003. Straight benthic flow-through flume for in situ measurement of cohesive sediment dynamics. Journal of Hydraulic Engineering 129(1),63-67.

[2] Darby, S.E., Rinaldi, M., \& Dapporto, S. 2007. Coupled simulations of fluvial erosion and mass wasting for cohesive river banks. Journal of Geophysical Research: Earth Surface ,112, F03022.

[3] Gharabaghi, B., Inkratas, C., Krishnappan, B.G., and, Rudra, R.P. 2007. Flow characteristics in a rotating circular flume. The Open Civil Engineering Journal 1, 30-36.

[4] Grabowski, R.C., Droppo, I.G., \& Wharton, G. 2011. Erodibility of cohesive sediment: The importance of sediment properties. EarthScience Reviews 105, 101-120.

[5] Hanson, G.J., \& Cook, K.R. 2004. Apparatus, test procedures, and analytical methods to measure soil erodibility in situ.Applied Engineering in Agriculture 20(4),455-462.

[6] Huang, J., Hilldale, R. C., \& Greimann, B.P. 2006. Cohesive sediment transport. Erosion and sedimentation manual, C.T. Yang, ed., The United States Department of Interior, Bureau of Reclamation, Technical Service Center, Denver, CO. 4.1-4.54.

[7] Kothyari, U.C., \& Jain, R. K. 2008. Influence of cohesive on the incipient motion condition of sediment mixtures. Water Resources Research, 44(4), W04410.

[8] Lawler, D.M. 1992. Design and installation of a novel automatic erosion monitoring system. Earth Surface Processes and Landforms 17, 455-463.

[9] Lawler, D.M. 1995. The impact of scale on the process of channel-side sediment supply: A conceptual model "Effects of scale on interpretation and management of sediment and water quality". International Association of Hydrological Sciences (IAHS), 226.175-184.

[10]Lim S.S., \& Khalili, N. 2009. An improved rotating cylinder test design for laboratory measurement of erosion in clayey soils. Geotechnical Testing Journal 32(3), 1-7.

[11] Papanicolaou, A.N., Elhakeem, M., \& Hilldale, R. 2007. Secondary current effects on cohesive river bank erosion. Water Resources Research 43(12), W12418.

[12] Papanicolaou, A.N., Sutarto, T.E., Wilson, C.G., Langendoen, E.J. 
2014. Bank Stability Analysis for Fluvial Erosion and Mass Failure. In: Proceeding of World Environmental and Water Resourcess Congress. Portland, Oregon, USA, 1-5 June 2014. Pp.1497-1508. doi:10.1061/9780784413548.150.

[13] Papanicolaou, A.N., Wilson C.G., Tsakiris, A.G., Sutarto, T.E., Bertrand, F., Rinaldi, M., Dey, S., \& Langendoen, E. 2017. Understanding mass fluvial erosion along a bank profile: Using PEEP technology for quantifying retreat lengths and identifying the event timing. Earth Surface Processes and Landform 42(11),1717-1732.

[14] Pizzuto, J. 2009. An empirical model of event scale cohesive bank profile evolution. Earth Surface Processes Landforms, 34(9).12341244.

[15] Rinaldi, M., \& Darby, S.E. 2008. Modeling river-bank-erosion processes and mass failure mechanisms: Progress towards fully coupled simulations. Gravelbed rivers VI: From process understanding to river restoration, H. Habersack, H. Piegay, and M. Rinaldi, eds., Elsevier, Amsterdam, the Netherlands. 213-239.

[16] Sutarto, T.E., \& Papanicolaou, A.N. 2012. Measuring Critical Erosion Strength of Cohesive Bank Soils in a Natural Channel Affected by Secondary Currents. In: Proceeding of the $3^{\text {rd }}$ International Symposium on Shallow Flows. Iowa City, USA, June, 2012.

[17] Sutarto, T.E., Papanicolaou, A.N., Wilson, C.G., \& Langendoen, E.J. 2014a. A stability analysis of semicohesive streambanks with CONCEPTS: Coupling field and laboratory investigations to quantify the onset of fluvial erosion and mass failure. Journal of Hydraulic Engineering, 140(9).

[18] Sutarto, T.E., Papanicolaou, A.N., Wilson, C.G., \& Langendoen, E.J. 2014b. Misconceptions about Mechanical and Fluvial Erosionnal Strength: Implications to Streambank Stability. In: Proceeding of the $2^{\text {nd }}$ International Seminar on Infrastructure Development. Balikpapan, Indonesia, 3-4 June, 2014.

[19] Sutarto, T.E. 2015. A combined flume-imaging technique for measuring fluvial erosion of cohesive streambank soil. Procedia Engineering, 125, 368-375.

[20] Sutarto, T.E. 2018. Teknik sensor cahaya untuk menentukan laju erosi tebing sungai. In: Proceeding of the $4^{\text {th }}$ SENTRINOV. Bali, Indonesia, 23-24 August, 2018.

[21] Vermeyen, T. 1995. Erosional and depositional characteristics of cohesive sediments found in Elephant Butte Reservoir, New Mexico. Technical report R-95-15, Water Resources Services, Technical Service Center, Bureau of Reclamation, Denver, USA. 

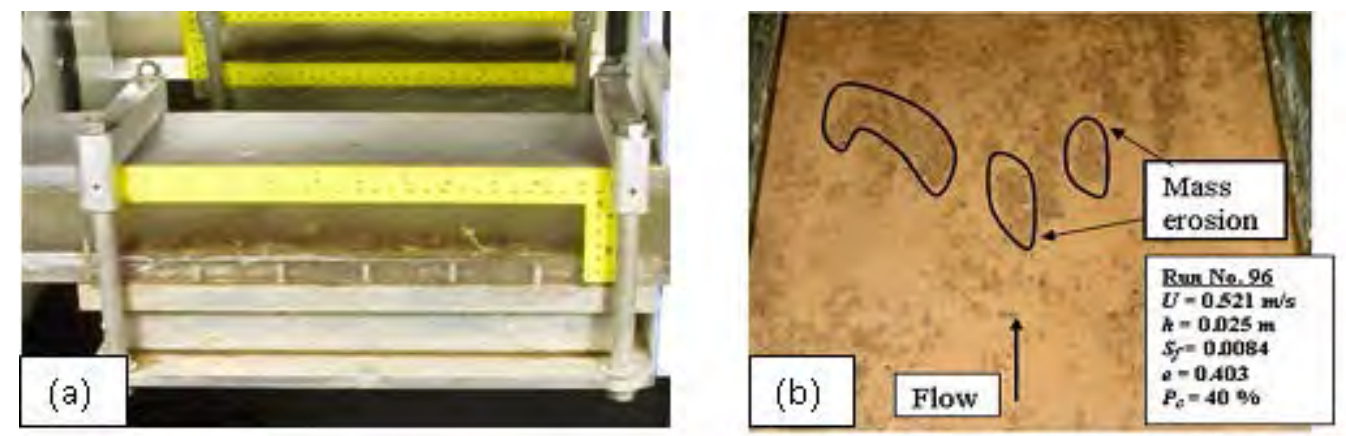

Gambar 1. (a) Sampel tanah mengalami gerusan butir (grain fluvial erosion) dalam eksperimen dengan conduit flume (Sutarto, 2015). (b) Permukaan tanah setelah mengalami gerusan bongkahan (mass fluvial erosion, Kothyari dan Jain, 2008).

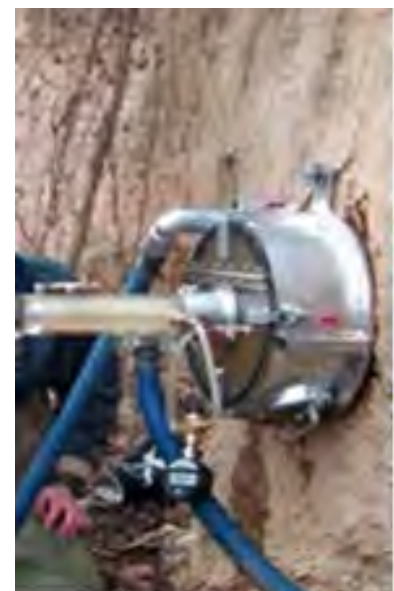

(a)
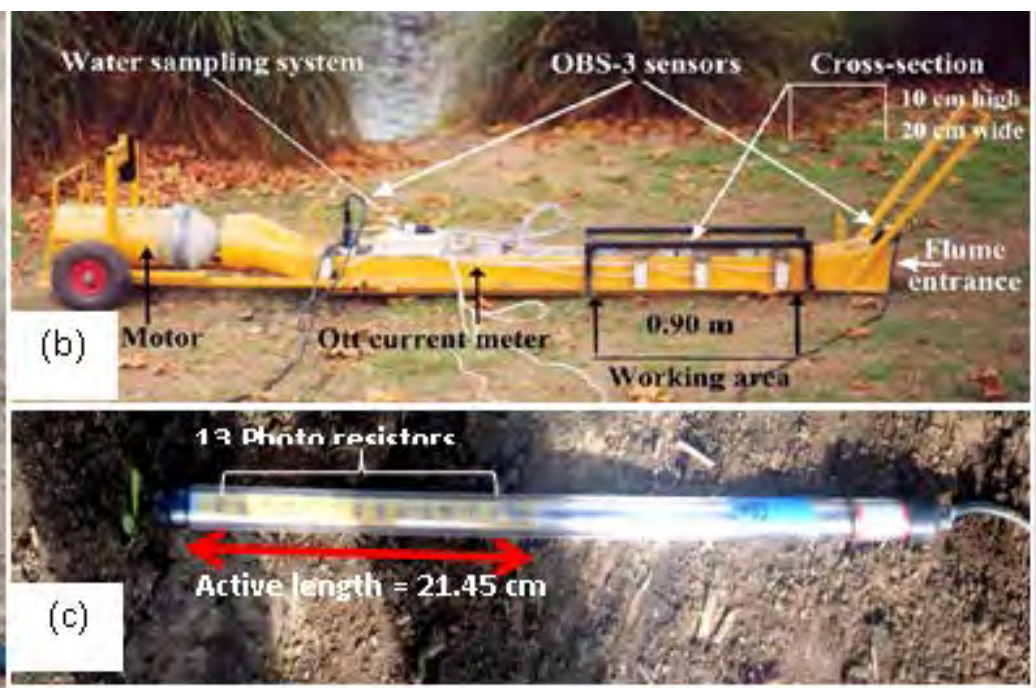

Gambar 2. Teknik Pengukuran Erosi Gerusan (Fluvial Erosion).

(a) Jet device (Hanson dan Cook, 2004). (b) Mini flume (Aberle dkk., 2004). (c) Photo Electronic Erosion Pin (PEEP) (Lawler, 1992)

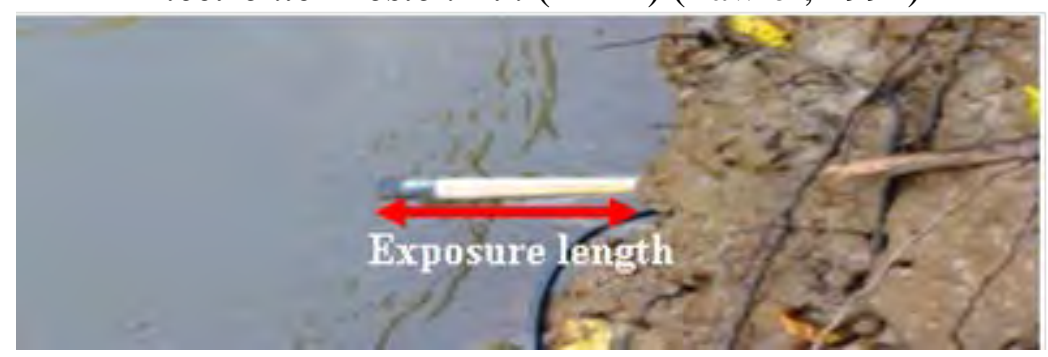

Gambar 3. Panjang Singkapan (Exposure Length) PEEP Setelah Kejadian Banjir 

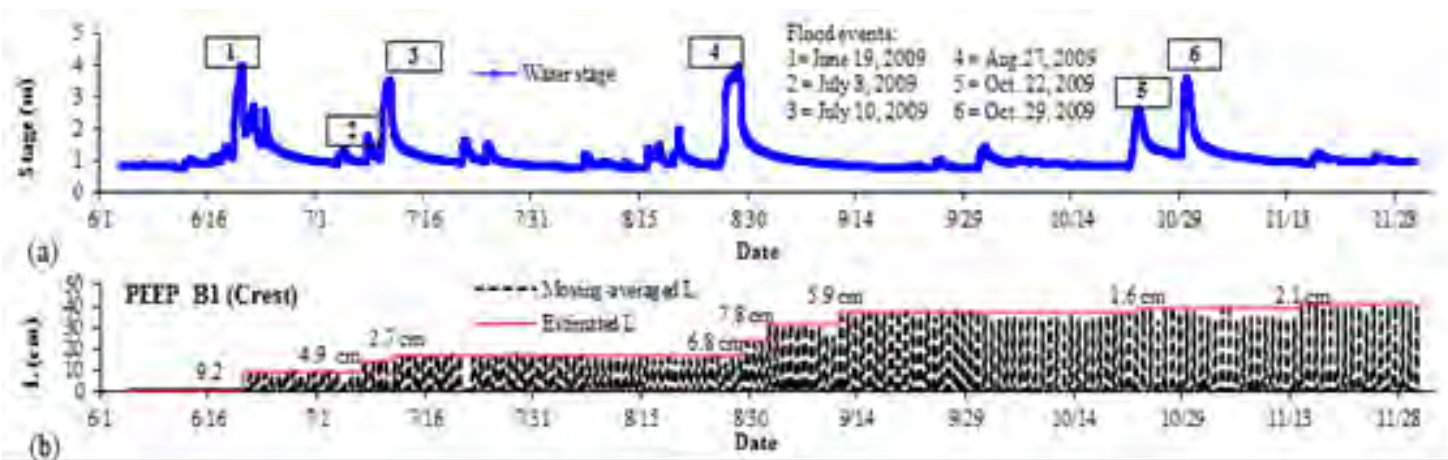

Gambar 4. (a) Serial data elevasi muka air (water stage) dalam sungai. (b) Panjang singkapan $L$ (exposure length) sensor PEEP B1.
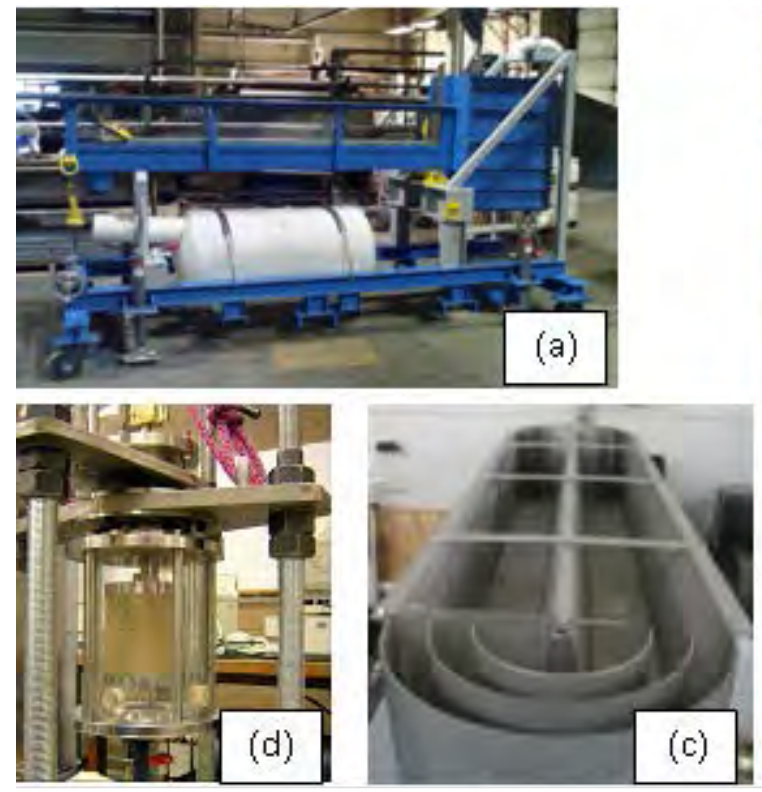

(c)

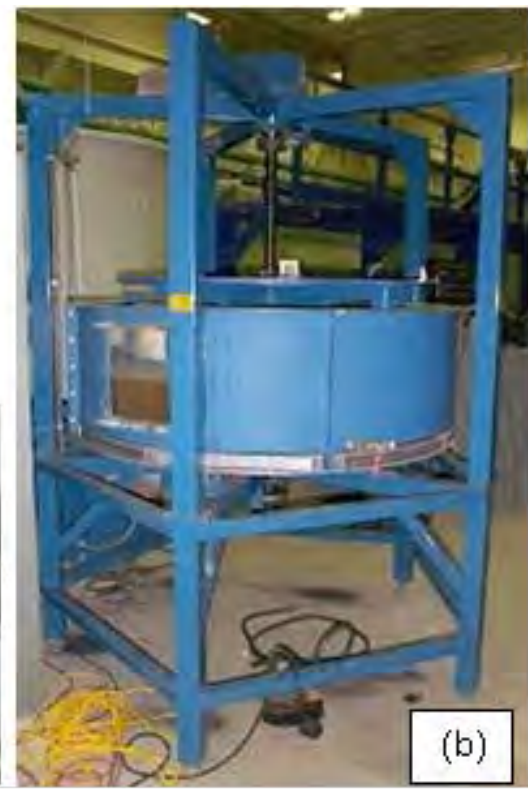

(b)

Gambar 5. (a) Saluran terbuka lurus. (b) Saluran terbuka berputar. (c) Saluran terbuka berbentuk jalur balap. (d) Silinder berputar.
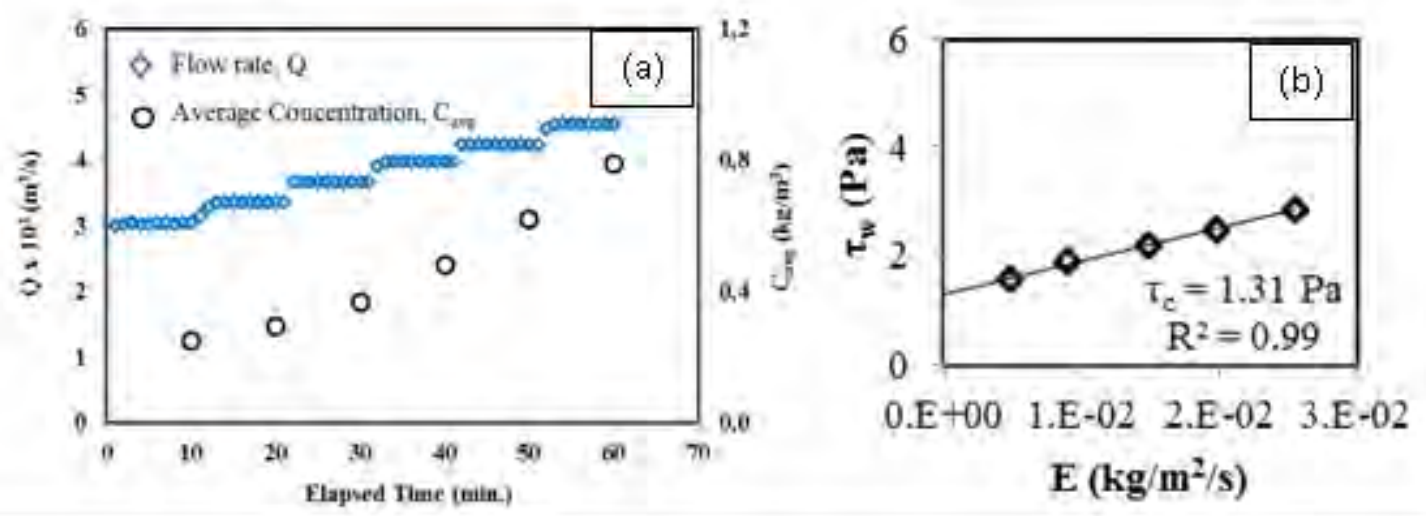

Gambar 6. (a) Peningkatan debit, $Q$, dan konsentrasi rerata sedimen terlarut $\left(C_{a v g}\right)$ selama eksperimen uji saluran . (b) Plot $\tau_{w}$ dan $E$ untuk menentukan nilai $\tau_{c}$. 


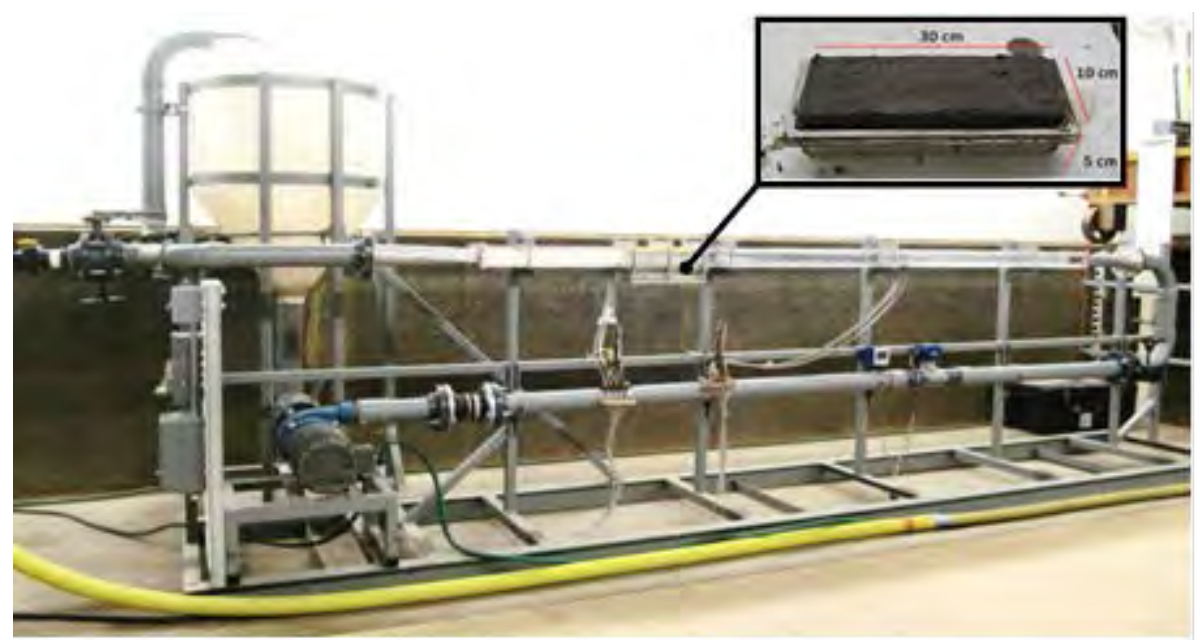

Gambar 7. Saluran Tertutup (Closed Conduit Flume) 
Tommy Ekamitra Sutarto, Tinjauan Ringkas Berbagai... 